\title{
Yield Responses of a Mature Olive Orchard to Water Deficits
}

\author{
Alfonso Moriana and Francisco Orgaz \\ IAS-CSIC, PO Box 4084, 14080 Cordoba, Spain \\ Miguel Pastor \\ CIFA Alameda del Obispo, PO Box 4240, 14004 Cordoba, Spain \\ Elias Fereres \\ IAS-CSIC and University of Cordoba, PO Box 4084, 14080 Cordoba, Spain
}

\begin{abstract}
AdDitional INDEX wORDs. Olea europaea, crop water production function, irrigation, stem water potential, regulated deficit irrigation, trunk diameter fluctuations, water relations

ABSTRaCt. Irrigation is one of the most important means of increasing olive oil production but little information exists on the responses of olive to variable water supply. Five different irrigation strategies, full irrigation, rain fed, and three deficit irrigation treatments were compared from 1996 to 1999, in Cordoba, southern Spain, to characterize the response of a mature olive (Olea europaea L. 'Picual') orchard to irrigation. Crop evapotranspiration (ET) varied from less than 500 $\mathrm{mm}$ in the rain fed to $\approx 900 \mathrm{~mm}$ under full irrigation. The deficit irrigation treatments had $\mathrm{ET}_{\mathrm{c}}$ values that ranged from $60 \%$ to $80 \%$ of full $\mathrm{ET}_{\mathrm{c}}$ depending on the year and treatment. Water relations, and oil content and trunk growth measurements allowed for the interpretation of yield responses to water deficits. In a deficit irrigation treatment that concentrated all its $\mathbf{E T}_{\mathrm{c}}$ deficit in the summer, stem water potential $\left(\Psi_{\mathrm{x}}\right)$ decreased to $-7 \mathrm{MPa}$ but recovered quickly in the fall, while in the treatment that applied the same ET deficit progressively, $\Psi_{x}$ was never below $-3.8 \mathrm{MPa}$. Minimum $\Psi_{\mathrm{x}}$ in the rain fed treatment reached $-8 \mathrm{MPa}$. Yield $(\mathrm{Y})$ responses as a function of $\mathrm{ET}_{\mathrm{c}}$ were calculated for biennial yield data, given the alternate bearing habit of the olive; the equation are: $\mathrm{Y}=-16.84+0.063 \mathrm{ET}-0.035 \times 10^{-3} \mathrm{ET}^{2}$, and $\mathrm{Y}=-2.78+0.011 \mathrm{ET}$ $-0.006 \times 10^{-3} \mathrm{ET}^{2}$, for fruit and oil production respectively, with responses to ET deficits being similar for sustained and regulated deficit irrigation. The yield response to a deficit treatment that was fully irrigated during the bearing year and rain fed in the nonbearing year, was less favorable than that observed in the other two deficit treatments.
\end{abstract}

The olive (Olea europaea L.) is, among fruit trees, an important source of both fruit and edible oil. Increased appreciation of olive oil as part of the Mediterranean diet (International Olive Oil Council, 2001) has raised olive oil prices, leading to an important increase in new plantings in many world areas. Additionally, there have been trends to intensify olive production, primarily via high-density plantings and irrigation. Because olive has been traditionally a rain-fed crop in the Mediterranean region, little information exists on its irrigation requirements, and even less on the responses to variations in irrigation water supply (Orgaz and Fereres, 1997).

New irrigation developments are under close scrutiny at present and the economic advantages of shifting olive plantations from traditional rain fed to irrigation must be clearly demonstrated before new water is allocated for irrigation. Many olive growing regions suffer chronic water shortages and increased competition from other sectors for the available water resources (Fereres and Ceña, 1997). A basic tool to assess the value of irrigation water is the crop water production function (Vaux and Pruitt, 1983). Crop biomass and yield are linearly related to evapotranspiration (ET) but the relations with applied irrigation water are usually curvilinear (Stewart and Hagan, 1973). Sometimes, nonlinear relations between yield and ET have been observed (i.e., cotton; Orgaz et al., 1992). It is important to characterize the production function of olive, a crop that has a reputation of being drought resistant. If the response to variation in ET is nonlinear, optimal ET levels can be defined for different oil and water prices and deficit irrigation programs to achieve such ET levels could be formulated.

Reports on the responses of olive yield to variable amounts of applied water differ according to different sources. Lavee et al.

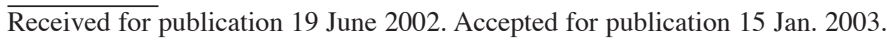
We thank Juan Castro, Francisco Camacho, Carmen Ruz and María Dolores Humanes for skillful technical assistance.
(1990) found that applications of 75, 150 and $200 \mathrm{~mm}$ in one, two or three irrigations over the season were about equally effective in increasing yields over rain fed conditions. Patumi et al. (1999) reported that irrigation significantly increased yield over rain fed conditions, but that applying 24,50 or $75 \mathrm{~mm}$ of water made no difference in the response. Pastor et al. (1999) showed a large yield increase $(\approx 100 \%)$ with irrigation over rain fed conditions in a 4-year experiment, but found no significant differences among treatments when 150,200 , and $320 \mathrm{~mm}$ of irrigation were applied to a mature traditional orchard in Jaen (Spain). In contrast to the results above, Baratta et al. (1986) found that 800 to $1000 \mathrm{~mm}$ of applied water were needed for maximum yields in Trapani (Italy) although they proposed that irrigation may be reduced after pit hardening. Goldhamer et al. (1994) found a linear relationship between yield and revenue, and applied water up to $950 \mathrm{~mm}$ in a mature orchard in the San Joaquin Valley of California. Subsequent research by Goldhamer (1999) suggested that irrigation may be reduced during the summer without a yield reduction. In other fruit trees, where irrigation is common, a practice called regulated deficit irrigation (RDI) has been proposed to reduce tree water use without a yield penalty (Chalmers et al., 1981; Mitchell et al., 1989). Under RDI, such reductions in irrigation need to be imposed at times when tree yield responses are minimally affected by water deficits (Boland et al., 2000a, 200b; Mitchell et al., 1989). It is therefore important to identify the periods when fruit trees are relatively insensitive to water deficits in order to design RDI strategies that conserve water (Fereres and Goldhamer, 1990).

This work was undertaken to characterize the response of a mature olive orchard to variable water supply and to study the water relations and the yield response under unlimited supply and rain fed conditions. Three deficit irrigation regimes were imposed to 1) identify effects of stress timing on tree responses and yield 
Table 1. Reference Evapotranspiration $\left(\mathrm{ET}_{\mathrm{o}}\right)$ and rainfall during the rainy $\left(\mathrm{P}_{\mathrm{r}}\right)$ and dry $\left(\mathrm{P}_{\mathrm{d}}\right)$ periods in the 3 experimental years.

\begin{tabular}{lccc}
\hline Year & $\begin{array}{c}\mathrm{ET}_{\mathrm{o}} \\
(\mathrm{mm})\end{array}$ & $\begin{array}{c}\mathrm{P}_{\mathrm{r}} \\
(\mathrm{mm})\end{array}$ & $\begin{array}{c}\mathrm{P}_{\mathrm{d}} \\
(\mathrm{mm})\end{array}$ \\
\hline 1997 & 1,328 & 1,039 & 3.9 \\
1998 & 1,389 & 395 & 11.9 \\
1999 & 1,543 & 463 & 4.9 \\
\hline
\end{tabular}

and to 2) develop the water production functions for olive fruit and oil yield under the experimental conditions.

\section{Materials and Methods}

Site DESCRIPTION AND EXPERIMENTAL DESIGN. The experiment was conducted between 1996 and 1999 in an 18-year-old olive (Olea europaea L. cv. Picual) orchard located at the CIFA Experimental Station, Cordoba, Spain $\left(38^{\circ} \mathrm{N}, 4.8^{\circ} \mathrm{W}, 110 \mathrm{~m}\right.$ altitude). The climate is Mediterranean with an average annual rainfall of 602 mm, mostly distributed outside a 4-month summer drought period. Annual rainfall between 1995 and 1999 was 478, 1095, 1043, 407 and $468 \mathrm{~mm}$, respectively. The soil is a Typic Xerofluvent of alluvial sandy loam texture and over $2 \mathrm{~m}$ deep. Tree spacing was $6 \times 6 \mathrm{~m}$; irrigation was applied $5 \mathrm{~d}$ a week, by the drip method with four (4 $\mathrm{L} \cdot \mathrm{h}^{1}$ ) emitters per tree. A randomized complete-block design was used with three replications of 16 trees each, and the following five irrigation treatments.

- A control treatment $(\mathrm{CON})$, that applied the estimated evapotranspiration $\left(\mathrm{ET}_{\mathrm{c}}\right)$ based on the fully replenishing soil water extraction.

- A regulated deficit irrigation treatment (RDI) that applied $75 \%$ of $\mathrm{ET}_{\mathrm{c}}$ (rainfall plus irrigation) with a midsummer (15 July to 15 September) deficit period without irrigation.

- A sustained deficit irrigation treatment (SDI) that also applied $75 \%$ of $\mathrm{ET}_{\mathrm{c}}$ (rainfall plus irrigation) but distributed as the same proportion of $\mathrm{ET}_{\mathrm{c}}$ throughout the irrigation season.

- Adeficit irrigation treatment (AYI) adapted to the alternate bearing habit of the olive; it was rain fed only during the years of little or no crop (1996 and 1998) and fully irrigated, as CON, during the heavy crop years (1997 and 1999).

- A rain fed treatment (DRY).

The orchard was in rain fed conditions until 1995 when irrigation was uniformly applied to the whole orchard. The first year of differential irrigation treatments (1996) has not been considered in the results. Leaf nutrient analyses in July were used every year to determine the fertilization needs. Table 1 presents the basic information on reference $\mathrm{ET}\left(\mathrm{ET}_{\mathrm{o}}\right)$ and rainfall for the experimental years.

IRRIGATION REGIMES. Applied water was calculated by estimating tree evapotranspiration $\left(\mathrm{ET}_{\mathrm{c}}\right)$ using tree canopy size and long-term average reference evapotranspiration $\left(\mathrm{ET}_{\mathrm{o}}\right)$ by using a model of olive tree transpiration (Villalobos et al., 2000). Evaporation from soil was estimated with Bonachela et al. (2001) model. During the experiment, actual precipitation was considered as part of applied water in RDI and SDI.

SOIL WATER AND EVAPOTRANSPIRATION MEASUREMENTS. Volumetric soil water content was measured with a neutron probe calibrated for the experimental soil with separate calibrations performed for the upper ( 0 to $0.30 \mathrm{~m}$ ) and lower (below $0.30 \mathrm{~m}$ ) layers. Eight access tubes, $2.5 \mathrm{~m}$ long, were placed between two trees per replicate plot in the four irrigated treatments and six tubes were placed in the rain fed treatment. The area occupied by a tree was divided into zones that were wetted by the emitters or not wetted. An access tube was placed in the center of each zone and its reading was taken as representative of the water content of the zone. A weighted average based on the area of each zone was performed to calculate the soil water content and the extraction by each tree. Measurements were taken every $15 \mathrm{~d}$ at various depths, starting at $0.075 \mathrm{~m}$ down to $2.25 \mathrm{~m}$. The upper limit (field capacity) of available water is $0.17 \mathrm{~cm}^{3} \cdot \mathrm{cm}^{-3}$ and the lower limit of available water (permanent wilting point) is $0.05 \mathrm{~cm}^{3 \cdot} \mathrm{cm}^{-3}$.

Crop evapotranspiration $\left(\mathrm{ET}_{\mathrm{c}}\right)$ was calculated by adding the two estimates of $\mathrm{ET}_{\mathrm{c}}$ during the rainy and the irrigation seasons. Deep percolation was assumed to be negligible based on subsoil water content measurements and on hydraulic conductivity estimates for the experimental soil. $\mathrm{ET}_{\mathrm{c}}$ was then calculated as

$$
\mathrm{ET}_{\mathrm{c}}=\left(\theta_{1}-\theta_{2}\right)+\mathrm{I}+\mathrm{R}
$$

where $\theta_{1}$ and $\theta_{2}$ are the volumetric water content of the first day and the last day, respectively, of the period considered, I is the amount of irrigation during the period considered, and $\mathrm{R}$ is the rain during the period considered (see Table 1).

During the rainy season, deep percolation did not allow for a precise $\mathrm{ET}_{\mathrm{c}}$ estimate using Eq. [1] so $\mathrm{ET}_{\mathrm{c}}$ was calculated with the FAO method (Doorenbos and Pruitt, 1974):

$$
\mathrm{ET}_{\mathrm{c}}=\mathrm{ET}_{\mathrm{o}} \times \mathrm{K}_{\mathrm{c}} \times \mathrm{K}_{\mathrm{r}}
$$

where $\mathrm{ET}_{\mathrm{o}}$ is the reference evapotranspiration, $\mathrm{K}_{\mathrm{c}}$ is crop coefficient, and $\mathrm{K}_{\mathrm{r}}$ is a coefficient to correct for incomplete cover.

During the rainy period, we assumed that the differences in $\mathrm{ET}_{\mathrm{c}}$ among treatments were small relative to the seasonal $\mathrm{ET}_{\mathrm{c}}$ because tree water status was similar among treatments (with the exception of the 1998 winter) and evaporative demand was low. Therefore, the same values of $\mathrm{K}_{\mathrm{c}}$ and $\mathrm{K}_{\mathrm{r}}$ were used in all the treatments. ET was estimated with the Penman-Monteith equation using daily data from an automatic weather station nearby (300 $\mathrm{m}$ away from the experimental orchard). The $\mathrm{K}_{\mathrm{c}}$ values are reported by Orgaz and Fereres (1997) while we estimated a value of 0.8 for $\mathrm{K}_{\mathrm{r}}$ (Fereres and Goldhamer, 1990).

Neutron probe measurements were combined with data on applied water measured volumetrically to determine $\mathrm{ET}_{\mathrm{c}}$ for the various treatments, as shown in Table 2 . The final measurements of $\mathrm{ET}_{\mathrm{c}}$ in each treatment (Table 2) indicated that water consumption of RDI was the $71 \%, 75 \%$, and $58 \%$ of $\mathrm{CON} \mathrm{ET}_{c}$, while the $\mathrm{ET}_{\mathrm{c}}$ of SDI was $79 \%, 81 \%$, and $62 \%$ of $\mathrm{CON} \mathrm{ET}_{\mathrm{c}}$, for 1997,1998 , and 1999, respectively.

\begin{tabular}{|c|c|c|c|c|c|c|}
\hline \multirow[b]{2}{*}{ Treatment } & \multicolumn{3}{|c|}{$\begin{array}{c}\text { AW } \\
(\mathrm{mm})\end{array}$} & \multicolumn{3}{|c|}{$\begin{array}{c}\mathrm{ET}_{\mathrm{c}} \\
(\mathrm{mm})\end{array}$} \\
\hline & 1997 & 1998 & 1999 & 1997 & 1998 & 1999 \\
\hline$\overline{\mathrm{CON}}$ & 509 & 454 & 734 & 814 & 778 & 899 \\
\hline RDI & 114 & 130 & 150 & 582 & 589 & 526 \\
\hline SDI & 147 & 112 & 239 & 649 & 636 & 562 \\
\hline AYI & 549 & 14 & 772 & 822 & 576 & 839 \\
\hline
\end{tabular}

Table 2. Applied water (AW) and crop evapotranspiration $\left(\mathrm{ET}_{\mathrm{c}}\right)$ in all the treatments during the 3 years of experiments. 
Plant water Relations and growth. As in pear trees (Naor, 2001), the level of crop load affects olive water relations (Moriana, 2001). Therefore, for the measurements that follow, four trees per treatment of one block with a similar, heavy crop load, were selected in 1998 to carry out the detailed water relations measurements. Those trees are referred hereafter as "on" trees. In 1999, the same measurements were performed in four different "on" trees of the same block, unless otherwise indicated. The objectives of the measurements were to document the underlying responses of the various treatments to the irrigation regimes. The wide variability in fruit load among trees of the same individual plots forced us to select trees with similar, heavy loads, for comparative purposes.

Stem water potential $\left(\Psi_{\mathrm{x}}\right)$ measurements were used to evaluate tree water status. Fully expanded leaves located in branches near the main trunk were covered with aluminium foil at least $1 \mathrm{~h}$ before excision and the water potential was measured with a pressure chamber at midday (Soil Moisture Equip., Santa Barbara, Calif.). Stem water potential was measured periodically, starting in 1998, in one leaf per tree on four "on" trees of one block per treatment.

Trunk diameter fluctuations (TDF) were measured with a linear variable differential transformer (LVDT) (model DF 2.5; Solartron Metrology, West Sussex, U.K.) mounted in a holder built of aluminum and INVAR, an alloy composed of $64 \% \mathrm{Fe}$ and $35 \% \mathrm{Ni}$ that has minimal thermal expansion. The four "on" trees where $\Psi_{\mathrm{x}}$ was measured were instrumented during 1998 and four "on" and four "off" trees, with little to negligible fruit load, were measured during 1999 in one block of all treatments except in the AYI treatment. The trees had three to four scaffolds emerging from the trunk, all $\approx 11.7 \mathrm{~cm}$ in diameter. The sensors were attached to the south main scaffold of each tree. Measurements were taken on each experimental tree every $30 \mathrm{~s}$ and the datalogger (model CR21X, Campbell Sci., Logan, Utah) was programmed to calculate 15 min means. The daily TDF cycle provides three different indices; maximum daily diameter (MXTD), minimum daily diameter (MNTD) and maximum daily shrinkage (MDS), the latter taken as the difference between MXTD and MNTD (Goldhamer and Fereres, 2001). The measurements (MDS) are presented relative to control values (RMDS).

Abaxial leaf conductance $\left(\mathrm{g}_{\mathrm{I}}\right)$ was measured in 1998 and 1999 with a transient porometer (model AP-4; $\Delta \mathrm{T}$, Cambridge, U.K.) between 1300 to $1600 \mathrm{HR}$ on three sunny, fully expanded leaves per tree and on four "on" trees per treatment.

Fruit AND OIL YIELD MEASUREMENTS. Thirty fruit of three trees per treatment and block were sampled periodically to determine oil content with Nuclear Magnetic Resonance (NMR), except in the AYI treatment, and the results were compared with LSD test. All of the experimental trees were harvested during winter (from 8 to 13 Jan. 1998, from 15 to 19 Dec. 1998 , and from 5 to 12 Jan. 2000 , respectively). Individual fruit weight of each tree was measured and a subsample of 150 fruit from each tree was obtained for oil content determinations and fruit weight. The oil and fruit yield results were analyzed with ANOVA and LSD tests using the SYSTAT program (SYSTAT 7.0 for Windows, SPSS Inc.).

\section{Results}

SoIL WATER CONTENT AND ET $\mathbf{E T}_{\mathrm{c}}$. Figure 1 presents the evolution of soil water content $\left(\theta_{v}\right)$ between 1997 and 1999. Heavy rains in the winter of 1997 prevented treatment differences until day 160 (Fig. 1a). From day 200 on, the $\theta_{v}$ of SDI decreased below those of $\mathrm{CON}$ and AYI treatments. Soil water content recovered following autumn rains and, by early 1998 , all treatments had the same $\theta_{v}$ (day
40, Fig. 1b). In the summer of $1998, \theta_{v}$ decreased sharply in all the treatments except in CON, where it remained $\approx 0.15 \mathrm{~cm}^{3} \cdot \mathrm{cm}^{-3}$ (Fig. 1b). Insufficient rainfall in the winter of 1998 did not allow for $\theta_{\mathrm{v}}$ recovery in all four (RDI, SDI, AYI and DRY) deficit treatments, so that in early spring of 1999 there were significant differences in $\theta_{v}$ (Fig. 1c). Clear differences were observed among all treatments throughout 1999 (Fig. 1c).

The seasonal $\mathrm{ET}_{\mathrm{c}}$ varied from less than 500 to nearly $900 \mathrm{~mm}$ (Table 2) with large differences among treatments and years. The higher $\mathrm{ET}_{\mathrm{o}}$ in 1999 produced higher differences in $\mathrm{ET}_{\mathrm{c}}$ among treatments. The maximum reduction in $\mathrm{ET}_{\mathrm{c}}$ caused by water deficits also occurred during 1999 season, the warmest year, when $\mathrm{ET}_{\mathrm{c}}$ of DRY treatment was less than $50 \%$ of $\mathrm{CON} \mathrm{ET}_{\text {c }}$. In AYI treatment, the lack of irrigation during 1998 reduced $\mathrm{ET}_{\mathrm{c}}$ but did not produce a clear reduction in the $\mathrm{ET}_{\mathrm{c}}$ of the following year when irrigation was resumed as in CON (Table 2).

Tree Water STATus. Midday stem water potential $\left(\Psi_{\mathrm{x}}\right)$ varied widely among treatments (Fig. 2). In 1998, $\Psi_{\mathrm{x}}$ in the deficit treatments departed from control values on day 163 and reached the greatest differences around mid-September (Fig. 2a). Recovery of $\Psi_{x}$ was apparently completed early following winter in 1999; however, the dry winter allowed for $\Psi_{x}$ differences to develop early
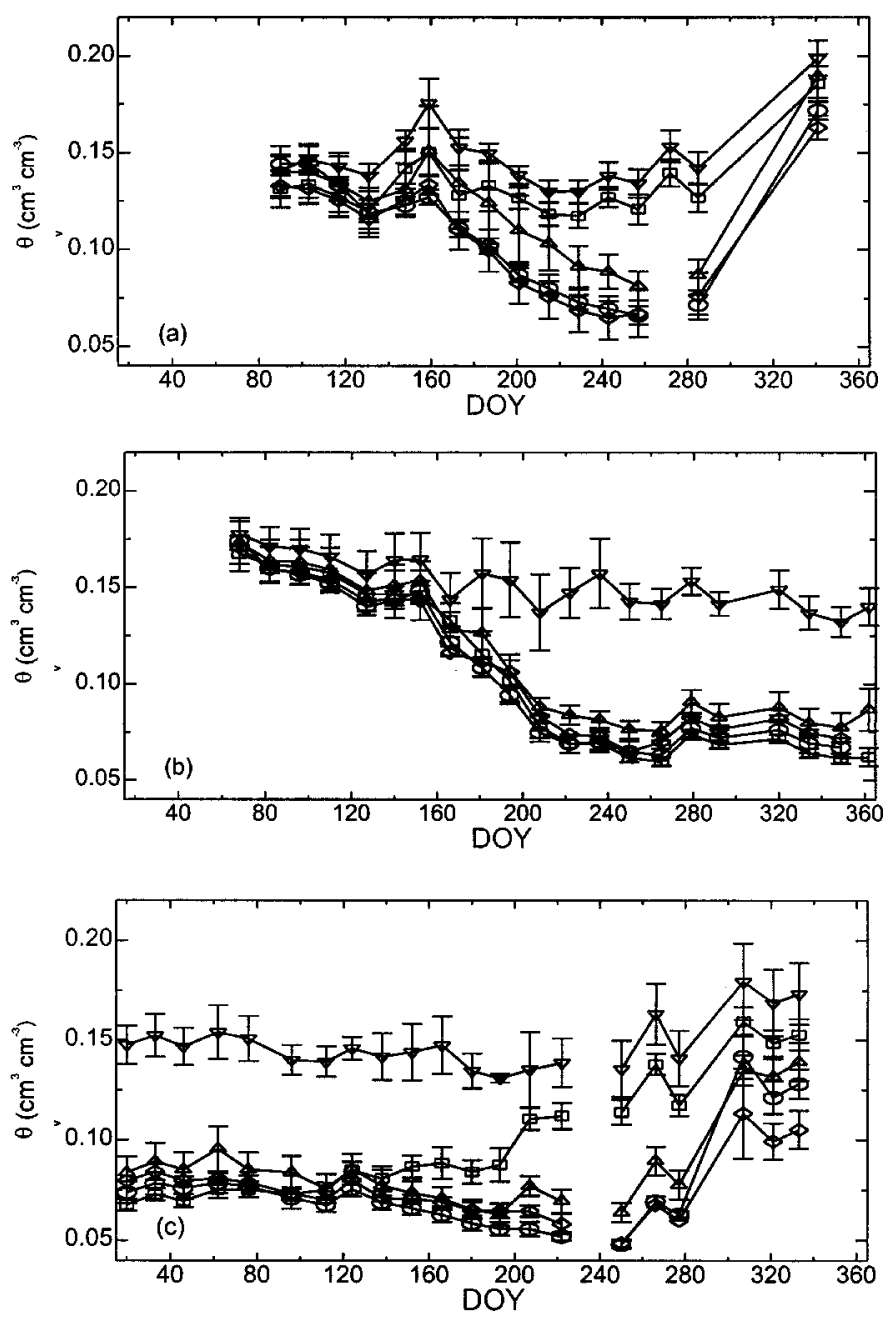

Fig. 1. Evolution of volumetric soil water content $\left(\theta_{v} ; \mathrm{cm}^{3} / \mathrm{cm}^{3}\right)$ during 1997,1998 and 1999 in $\operatorname{CON}(\nabla)$, RDI $(\diamond)$, SDI $(\Delta)$, AYI $(\square)$, and DRY $(\bigcirc)$ treatments. Each point is the weighed average for the total $2.4-\mathrm{m}$ profile of each set of eight access tubes, also averaged for the three replicate plots. The vertical bars represent twice the standard error. 

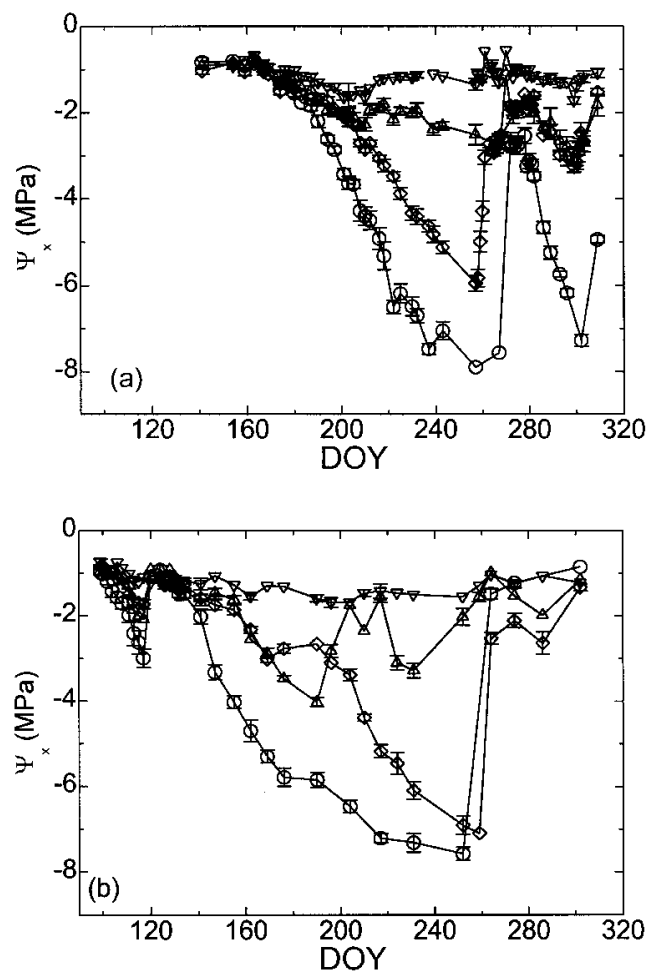

Fig. 2. Evolution of midday stem water potential during 1998 and 1999 in CON $(\nabla)$, RDI $(\diamond)$, SDI $(\Delta)$, and DRY $(\bigcirc)$ treatments. Each point is the average of four measurements and the vertical bars represent twice the standard error.

in the Spring, when $\Psi_{\mathrm{x}}$ reached $-3 \mathrm{MPa}$ in DRY before the rains (after day 120) allowed for complete recovery (Fig 2b). Soon after, $\Psi_{\mathrm{x}}$ declined again in the deficit treatments until day 255 , when it reached very low values in RDI and DRY (nearly -8.0 MPa) and then recovered after day 265 (Fig. 2b).

Relative maximum daily shrinkage (RMDS) varied from almost 3 to less than 0.3 in the stressed treatments (Fig. 3). During 1998, the highest RMDS values were recorded in late spring in RDI and DRY while the minimum values were also observed in the stressed treatments at the end of the summer drought, when RDI and DRY exhibited RMDS values well below 1 . However, the RMDS of SDI remained above that of CON (Fig. 3a). In 1999, treatment differences in RMDS values were less pronounced (Fig. 3b).

In 1998 midday leaf conductance $\left(\mathrm{g}_{1}\right)$ was similar in all treatments until day 180, when it started to decrease in the deficit treatments (Fig. 4a). The greatest $g_{1}$ differences were observed by the end of the summer, when $g_{1}$ of DRY was a small fraction of the control values. Following autumn rains, $\mathrm{g}_{1}$ recovered, although recovery was not complete (Fig. 4a). At the start of the measurements in 1999 there were differences in $\mathrm{g}_{1}$ among treatments (Fig. 4b). The effects of insufficient winter rainfall led to very low $\mathrm{g}_{\mathrm{l}}$ values in DRY from the start of the measurements. From day 160 on, $g_{1}$ of DRY reached a minimum value of $20 \mathrm{mmol} \cdot \mathrm{m}^{-2} \cdot \mathrm{s}^{-1}$ and stayed around there until the autumn rains (Fig. 4b). By contrast, $\mathrm{g}_{1}$ of SDI and RDI decreased until day 250 when $\mathrm{g}_{1}$ of RDI had values similar to those of DRY. Irrigation during autumn in RDI caused a complete recovery in the $\mathrm{g}_{1}$ of RDI, up to control values, while recovery in DRY was incomplete despite substantial rainfall $(\approx 60$ $\mathrm{mm}$ on day 260 and $16 \mathrm{~mm}$ on day 285).

TrunK AND FRUIT GROWTH. Figure 5 presents the seasonal patterns of trunk growth for 1999; in this season, the records for "off" trees in $\mathrm{CON}$ are also included. Trunk growth of CON trees depended on their fruit load; "off" trees grew more or less at a constant rate
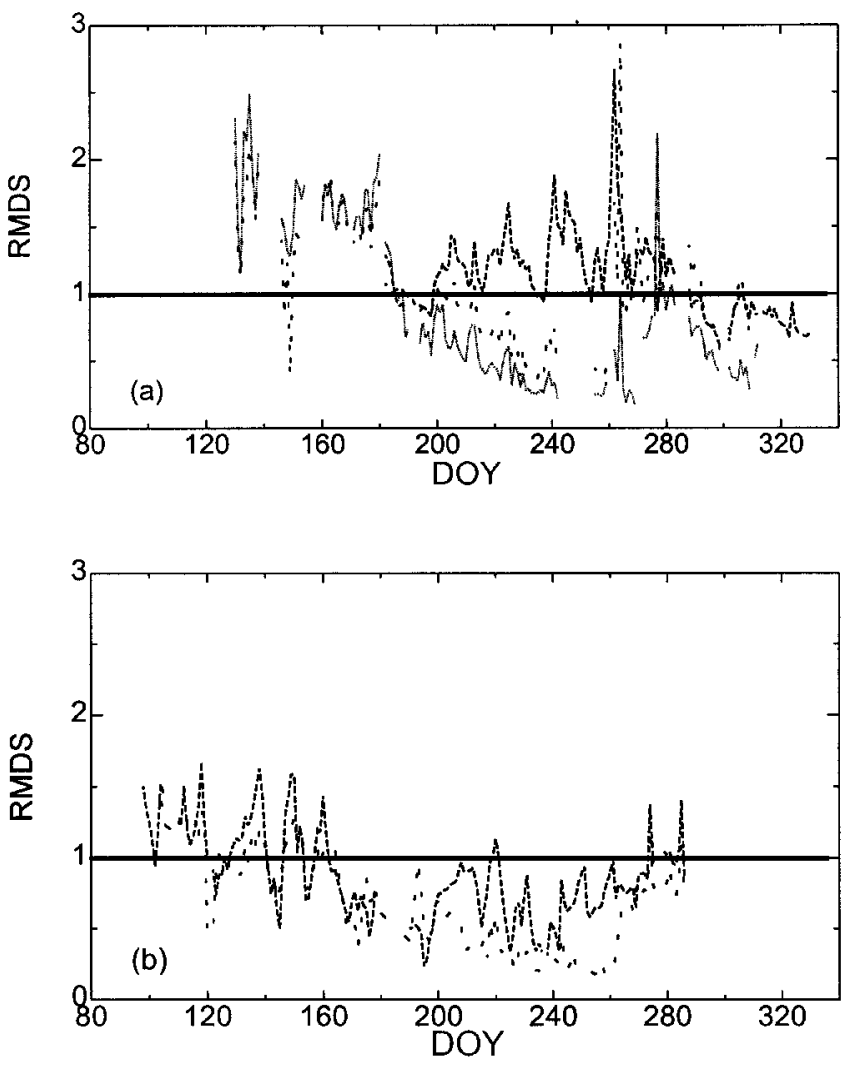

Fig. 3. Maximum daily shrinkage (RMDS) of all stressed treatments relative to CON during 1998 and 1999 measured in trees with a heavy crop load in RDI (- - ), SDI (---), and DRY (....) treatments (DRY for 1998 only).
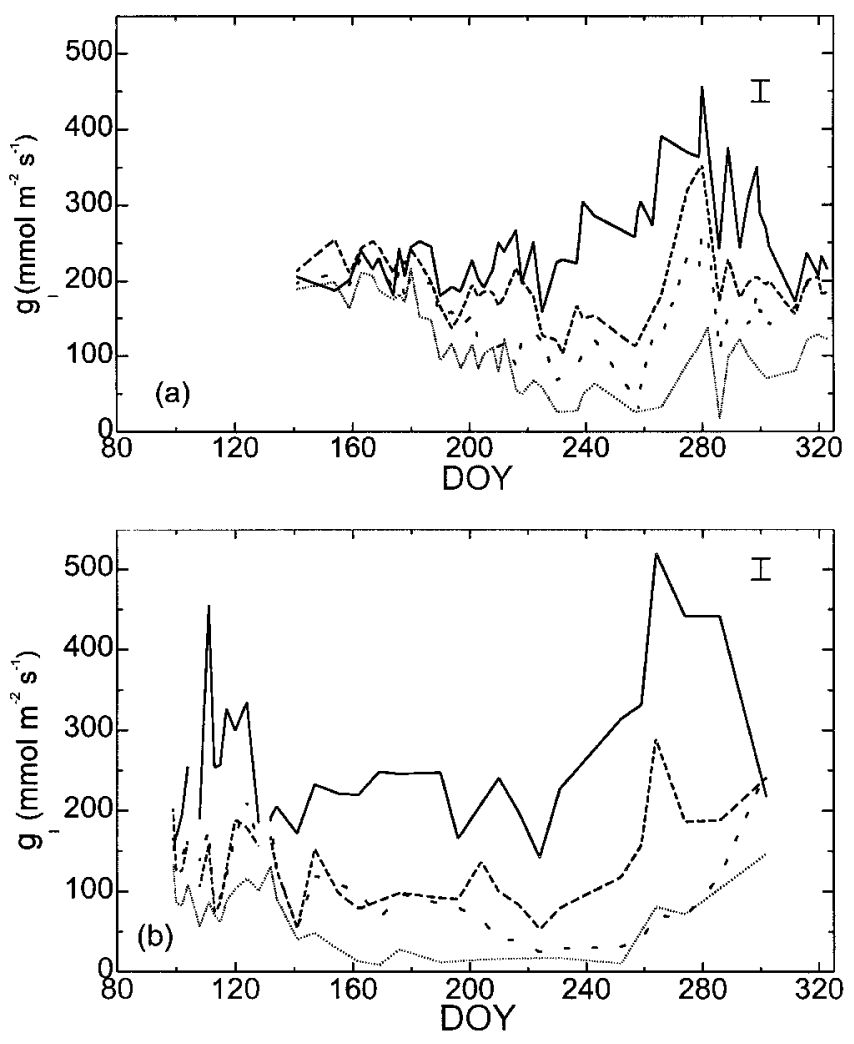

Fig. 4. Evolution of midday leaf conductance $\left(\mathrm{g}_{1}\right)$ during 1998 and 1999 in CON (-), RDI(- - -), SDI (---), and DRY (....) treatments. Vertical bars represent twice the standard error. 


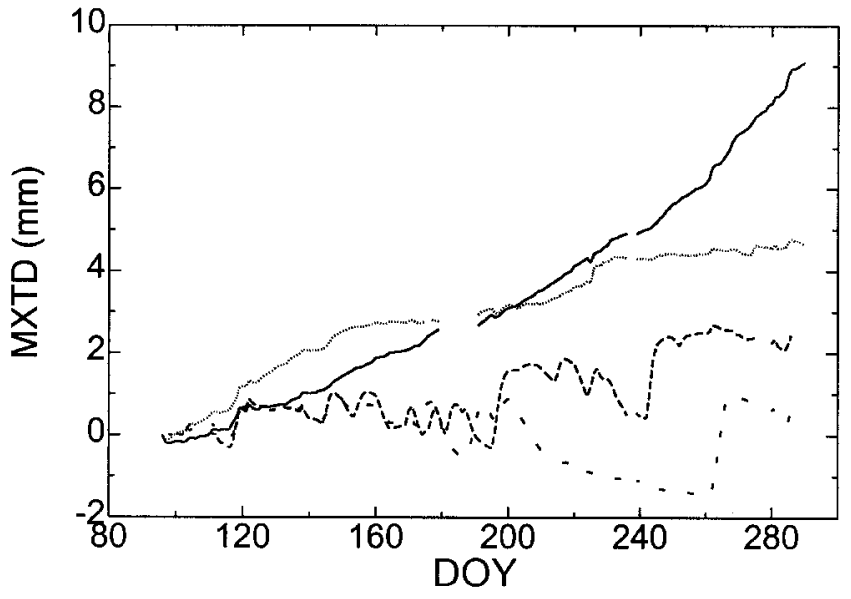

Fig. 5. Evolution of maximum trunk diameter (MXTD) during 1999 in: CON ('on' trees) (-), CON ('off' trees) (....), RDI (- - -), and SDI (---) treatments.

throughout the season, while growth of "on" trees nearly stopped at about day 150, resumed at a slow rate in midsummer and stopped again during autumn (Fig 5). The trunks of all other treatments did not grow but rather shrunk slightly, exhibiting greater decreases in diameter during the periods of severe water stress and then recovered following rains (Fig. 5). Similar patterns of trunk growth were measured during the 1998 season (data not shown).

Oil accumulation in the fruit was affected by the irrigation treatment. A distinct pattern was observed during the three years and fruit of both RDI and SDI accumulated oil more rapidly that CON fruit. Figure 6 presents the oil accumulation in 1998 and 1999. Full irrigation delayed oil accumulation while the response of the rain fed treatment varied with year (Fig. 6).

Fruit PRODUCTION, OIL YIELD AND YIELD COMPONENTS. There were large tree to tree variations in fruit and oil yield due to alternate bearing patterns. Because of the alternate bearing pattern of fruit and oil production, biennial production of each replicate plot was calculated. Significant differences among irrigation treatments (according to the LSD test) were found in the biennial yield (Table 3 ). To assess the pattern of yield response to variations in $\mathrm{ET}_{\mathrm{c}}$, we used biennial data from individual replicate plots where we had both yield and $\mathrm{ET}_{\mathrm{c}}$ data, to carry out a regression analysis (Fig. 7). The data from one replicate plot of CON and another of RDI were not represented in Fig. 7 because after 1998, the trees where the access tubes were located, had clear symptoms of verticillium wilt, a vascular fungi (Verticillium dahliae Kleb.) that probably affected the transpiration of those particular trees. Also not included in the calculation of the $\mathrm{Y}-\mathrm{ET}_{\mathrm{c}}$ relationship, were the three replicate points of AYI for 1998/99 (Fig. 7), where the unusual 1998/99 winter drought significantly reduced yield in that treatment. The best fit of both $\mathrm{Y}-\mathrm{ET}_{\mathrm{c}}$ relationships were curvilinear, having greater coefficients of determination and lower mean square errors than the linear regressions $\left(R^{2} 0.71\right.$ and 0.66 for fruit and 0.59 and 0.55 for oil, respectively). Table 4 presents the average number of fruit and individual fruit weight for all the treatments and for the three years. The big oscillations in the fruit numbers and the fruit weight among treatments and years are more extreme in the DRY and AYI treatments than in the other three.

\section{Discussion}

Our deficit treatments were designed to compare three means of reducing ET; by sustained deficit (SDI), by concentrating the
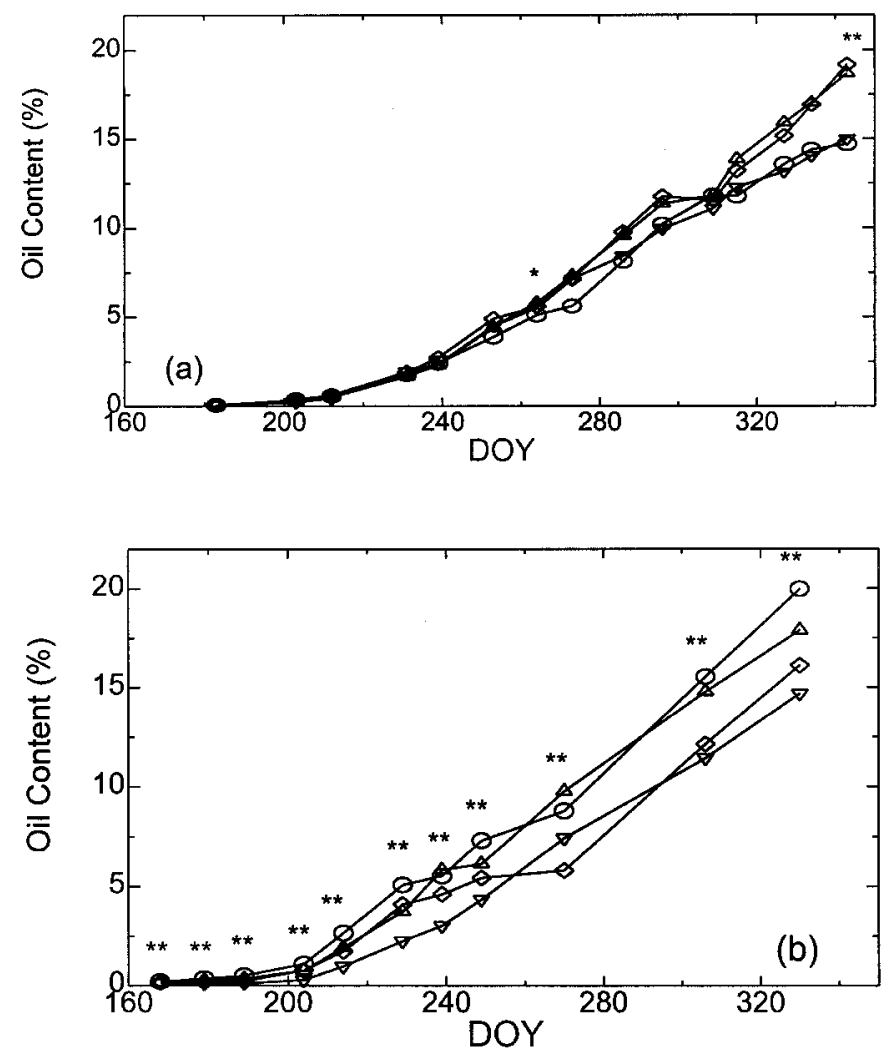

Fig. 6. Evolution of fruit oil content (\% fresh weight) during 1998 and 1999 seasons in $\operatorname{CON}(\nabla) ; \operatorname{RDI}(\diamond) ; \operatorname{SDI}(\Delta)$; and DRY $(\bigcirc)$ treatments. Each point is the average of 9 measurements. ${ }^{* * *}$ Significant differences in the LSD test at $P<0.05$ or 0.01 , respectively.

stress during an insensitive period which also has high evaporative demand (RDI), and by reducing ET during the nonbearing year (AYI). Research on yield responses to ET deficits have shown that most water production functions of row crops are linear (Vaux and Pruitt, 1983). By contrast, similar investigations with fruit trees strongly suggest that there are crop developmental periods where stress is not detrimental to yield, giving way to deficit irrigation strategies that can reduce ET while maintaining yield (Chalmers et al., 1981; Mitchell et al., 1989). The nonlinear response of olive yield to ET deficits shown in Fig. 7 indicates that water productivity was not constant in our experiment; rather, it varied from $22 \mathrm{~kg} \cdot \mathrm{ha}^{-1} \cdot \mathrm{mm}^{-1}$ at low $\mathrm{ET}_{\mathrm{c}}$ (for 450 to $550 \mathrm{~mm}$ range) to $\approx 9 \mathrm{~kg} \cdot \mathrm{ha}^{-1} \cdot \mathrm{mm}^{-1}$ when $\mathrm{ET}_{\mathrm{c}}$ approached maximum ET (for 750 to $850 \mathrm{~mm}$ range) in fruit production and from $5 \mathrm{~kg} \cdot \mathrm{ha}^{-1} \cdot \mathrm{mm}^{-1}$ to $\approx 0.2$ $\mathrm{kg} \cdot \mathrm{ha}^{-1} \cdot \mathrm{mm}^{-1}$ in oil production. In olive, Goldhamer (1999) found

Table 3. Fruit and oil yields (means and standard errors) computed in biennial periods for the 3 experimental years.

\begin{tabular}{lccccc}
\hline & \multicolumn{2}{c}{$1997-98$} & & \multicolumn{2}{c}{$1998-99$} \\
\cline { 2 - 3 } \cline { 5 - 6 } Treatment & $\begin{array}{c}\text { Fruit } \\
\left(\mathrm{t} \mathrm{ha}^{-1}\right)\end{array}$ & $\begin{array}{c}\text { Oil } \\
\left(\mathrm{t} \mathrm{ha}^{-1}\right)\end{array}$ & & $\begin{array}{c}\text { Fruit } \\
\left(\mathrm{t} \mathrm{ha}^{-1}\right)\end{array}$ & $\begin{array}{c}\text { Oil } \\
\left(\mathrm{t} \mathrm{ha}^{-1}\right)\end{array}$ \\
\hline CON & $11.6 \pm 0.4 \mathrm{a}^{\mathrm{z}}$ & $1.9 \pm 0.0 \mathrm{a}$ & & $10.6 \pm 0.2 \mathrm{a}$ & $2.0 \pm 0.1 \mathrm{a}$ \\
RDI & $9.3 \pm 1.2 \mathrm{~b}$ & $1.6 \pm 0.2 \mathrm{ab}$ & & $7.0 \pm 0.1 \mathrm{~b}$ & $1.5 \pm 0.1 \mathrm{ab}$ \\
SDI & $9.7 \pm 0.6 \mathrm{ab}$ & $1.8 \pm 0.1 \mathrm{ab}$ & & $7.2 \pm 0.6 \mathrm{~b}$ & $1.5 \pm 0.1 \mathrm{ab}$ \\
AYI & $9.2 \pm 0.8 \mathrm{~b}$ & $1.5 \pm 0.2 \mathrm{ab}$ & & $6.4 \pm 0.5 \mathrm{bc}$ & $1.4 \pm 0.1 \mathrm{~b}$ \\
DRY & $7.9 \pm 0.7 \mathrm{~b}$ & $1.4 \pm 0.2 \mathrm{~b}$ & & $5.1 \pm 0.7 \mathrm{c}$ & $0.9 \pm 0.2 \mathrm{c}$ \\
\hline
\end{tabular}

zTreatments with the same letter are not significantly different by LSD test at $P \leq 0.05$. 

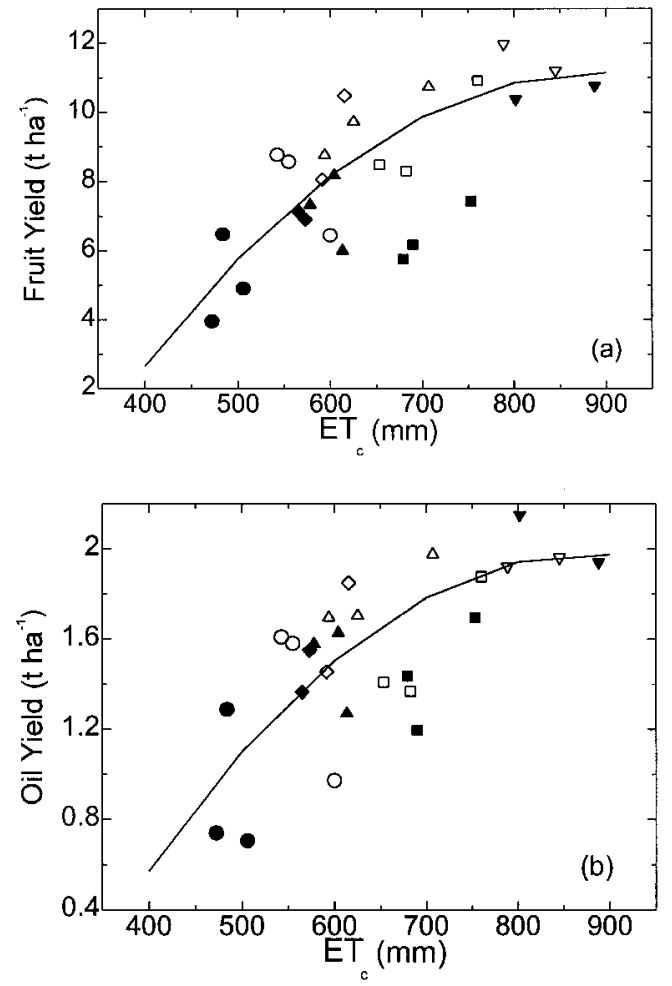

Fig. 7. Relationship between a) fruit yield $\left(t \cdot h a^{-1}\right)$ and b) oil yield $\left(t \cdot h a^{-1}\right)$ against olive evapotranspiration $\left(\mathrm{ET}_{\mathrm{c}}, \mathrm{mm}\right)$. Points represent yield and $\mathrm{ET}_{\mathrm{c}}$ biennial averages for each replicate plot. Empty symbols correspond to 1997-98, while full symbols correspond to 1998-99 for $\operatorname{CON}(\nabla, \nabla)$; RDI $(\diamond, \diamond)$; SDI $(\Delta, \boldsymbol{\Delta})$; AYI $(\square, \mathbf{\square})$; and DRY $(\bigcirc, \bigcirc)$ treatments. The best fit relationships are (a) for yield; $\mathrm{Y}=-16.84+0.063 \mathrm{ET}-0.035 \times 10^{-3} \mathrm{ET}^{2} ; R^{2}=0.71 ; P<$ $0.001 ; \mathrm{RMSE}=1.2 ; \mathrm{n}=23$ and $(\mathbf{b})$ for oil; $\mathrm{Y}=-2.78+0.011 \mathrm{ET}-0.006 \times$ $10^{-3} \mathrm{ET}^{2} ; R^{2}=0.59 ; P<0.001 ; \mathrm{RMSE}=0.3 ; \mathrm{n}=23$. The three data points of the AYI treatment in 1998/99 were not included in the regression analyses. For explanation see text.

that a reduction in applied water during midsummer of $15 \%$ and $25 \%$ of the seasonal application for maximum yield, did not have a negative impact on canning olive yields. A more severe deficit imposed by a $44 \%$ reduction in applied water, decreased yields by only $10 \%$. Goldhamer (1999) did not report ET values for the different treatments, but considering that the predawn water potential values reported did not decrease below $-0.9 \mathrm{MPa}$ in the $15 \%$ and $25 \%$ applied water deficit treatments, it appears that the reductions in applied water in his experiment were not directly translated into ET deficits, hence the lack of yield response. Assuming a soil water extraction of $\approx 150 \mathrm{~mm}$ in the most severe deficit case (D.A. Goldhamer, personal communication), the severe stress treatment must have had an ET deficit of $\approx 25 \%$ to $30 \%$, with a yield decrease of $\approx 10 \%$ below the maximum (Goldhammer, 1999), a very similar response to that depicted in Fig. 7.
The oil yield-ET $\mathrm{ET}_{\mathrm{c}}$ response was very similar to the fruit-ET because the differences in oil content among treatments (Fig 6) were compensated by the differences in fruit size (Table 4). In several irrigation experiments in olive trees (Lavee and Wodner, 1991; Pastor et al., 1999; Patumi et al., 1999) reported that oil content in the rain fed treatment was the same, or even higher than the irrigated trees. The increase in fruit oil content in the water-stressed treatments may be explained by the release of stress during the last period of oil accumulation in the fall (Fig. 2) and by the lower fruit numbers per tree in those treatments (Table 4). Inglese et al. (1996) reported higher oil content in the fruit of rain fed trees that were irrigated during the last phase of fruit growth. The favorable response of the deficit treatments is related to the normal rainfall patterns in Mediterranean climates and to the lower fruit load of the stressed trees.

The plasticity of the yield components in the olive in response to water was remarkable (Table 4). The DRY treatment varied fruit number and weight drastically in response to the level of water stress; in 1999 the severity of stress (Fig. 2b) led to very small fruit. The compensatory features of fruit number and weight in the other treatments were also apparent (Table 4) and suggest a significant capacity for recovery. Lavee and Wodner (1991) reported that olive fruit recovered dramatically following the release of water stress. The trunk growth patterns and the yield responses of the stressed trees suggest a shift in assimilate partitioning toward greater dry matter accumulation in the fruit of olive trees subjected to water deficits. Changes in dry matter partitioning are the basis for the RDI strategies in deciduous fruit trees (Chalmers et al., 1981; Mitchell et al., 1989).

It has been customary in the study of yield responses to irrigation, to emphasize the variable responses depending on the sensitivity of crop developmental stages to water deficits (Doorenbos and Kassam, 1979). In olive, it has been suggested that the most tolerant stress period occurs in midsummer (Baratta et al., 1986; Goldhamer, 1999; Orgaz and Fereres, 1997) and our hypothesis was that RDI should have had a more favorable yield response to ET deficits than SDI. The average reductions in $\mathrm{ET}_{\mathrm{c}}$ and in yield in RDI and SDI were similar (Tables 2 and 3) and the scatter among individual replicate plots in the $\mathrm{Y}-\mathrm{ET}_{\mathrm{c}}$ relationship (Fig. 7 a and b), strongly suggest that there were no yield response differences between progressive stress (SDI) and the summer-concentrated stress (RDI). There were certainly major differences in the level of plant water stress experienced by both treatments; $\Psi_{\mathrm{x}}$ of RDI declined sharply in the summer several MPa below that of SDI (Fig. 2). If an integrated value of $\Psi_{x}$ would have been used as an indicator of tree response (Ginestar and Castel, 1996) RDI yield should have been much less than SDI, which was not the case. The lower $\Psi_{\mathrm{x}}$ of RDI was associated with lower $\mathrm{g}_{1}$ values (Fig. 4) and presumably, lower photosynthesis (Moriana et al., 2002). Nevertheless, such differences in seasonal leaf conductance and in

Table 4. Number of fruit per tree and fruit weight (g) for all treatments and the 3 experimental years.

\begin{tabular}{|c|c|c|c|c|c|c|}
\hline \multirow[b]{3}{*}{ Treatment } & \multicolumn{2}{|c|}{1997} & \multicolumn{2}{|c|}{1998} & \multicolumn{2}{|c|}{1999} \\
\hline & Fruit & $\mathrm{Wt}$ & Fruit & $\mathrm{Wt}$ & Fruit & $\mathrm{Wt}$ \\
\hline & no. & (g) & no. & $(\mathrm{g})$ & no. & (g) \\
\hline$\overline{\mathrm{CON}}$ & $22698 a^{z}$ & $2.36 \mathrm{a}$ & $18526 \mathrm{a}$ & $1.50 \mathrm{a}$ & $34871 \mathrm{a}$ & $1.35 \mathrm{ab}$ \\
\hline SDI & $16790 \mathrm{ab}$ & $2.37 \mathrm{a}$ & $19689 a$ & $1.37 \mathrm{a}$ & $18014 \mathrm{ab}$ & $1.73 \mathrm{a}$ \\
\hline AYI & $23863 \mathrm{a}$ & $2.69 \mathrm{a}$ & 3077 b & $1.21 \mathrm{a}$ & $20604 \mathrm{ab}$ & $2.13 \mathrm{a}$ \\
\hline
\end{tabular}

zTreatments with the same letter are not significantly different by LSD test at $P \leq 0.05$. 
the other water relations parameters, apparently did not translate into yield differences between RDI and SDI. It should be pointed out, however, that our individual tree yield records indicate that the yields of the four RDI trees where the water relations parameters were measured, were $\approx 11 \%$ less on the average, than those of the four SDI trees also monitored in detail (Moriana, 2001).

The reactions of individual trees to the irrigation regimes were clearly captured by the water relations measurements (Figs. 2-5). Among them, our results indicated that trunk growth is extremely sensitive to water deficits (Fig. 5). We also detected large differences in the seasonal pattern of trunk growth depending on crop load (Fig. 5). Trees with heavy fruit load exhibited the most active trunk growth until $\approx 4$ weeks after full bloom, as shown for other olive shoot growth parameters by Rallo and Suarez (1989), and then grew very slowly for the rest of the year, while trees with a light crop load grew steadily throughout the season at an increasing rate (Fig. 5). There was hardly any increase in trunk diameter in the stressed treatments and here again, SDI differed from RDI in the same fashion as the other water relation parameters (Figs. 2-4).

The yield response of AYI offers an interesting contrast with the response patterns of all other stressed treatments. Following full irrigation in 1997 and very high yields (Table 4), AYI developed under rain fed conditions in 1998, completely depleted the soil profile by the end of the year (Fig 1b), even beyond that of DRY. The severe drought in the fall of 1998 reduced AYI yields substantially, relative to CON yields. The unusual drought during the Winter 1998/99 and a delay in the start of irrigation, kept the soil moisture in AYI at very low levels until day 150 in 1999 (Fig. 1c) and that apparently had an important impact in the flowering and fruit set in that treatment. Our estimates of fruit numbers in AYI in 1999 were only $59 \%$ of CON and, even though there was some compensation in fruit size, AYI yields for the biennial 98/99 period were less than what could be predicted from the generalized response depicted in Fig. 7. Therefore the data points of AYI for 1998/99 were not included in the regression analysis for the development of the yield response function to ET.

It has been suggested that withholding water during the "off" year may not harm "on" year yields in pistachio trees (Stevenson and Shackel, 1998). Nevertheless, our results cast doubts on the viability of the AYI program in olive. Because of the severe drought during the rain fed period of 1998, AYI experienced water stress in the fall, when the fruit were filling and in the spring of 1999, when fruit set for the next crop was being determined. The unusual lack of rainfall during the winter season of 1998/99 had a more negative impact on the water productivity of AYI than on that of the other stressed treatments. Results from more experimental years are probably needed before reaching any firm conclusions on the potential of AYI as a deficit irrigation strategy; nevertheless, water deficits applied, either during midsummer or progressively during the whole season, appear to be about equally effective for reducing olive ET in situations where full irrigation supply is not a viable strategy.

\section{Literature Cited}

Baratta, B., T. Caruso, L. Di Marco, and P. Inglese. 1986. Effects of irrigation on characteristics of olives in 'Noceralla del Belice' variety. Olea 17:195-198.

Boland,A.M.,P.H. Jerie, P.D. Mitchell, and I. Goodwin. 2000a. Long-term of restricted root volume and regulated deficit irrigation on peach: I. Growth and mineral nutrition. J. Amer. Soc. Hort. Sci. 125:135-142.

Boland, A.M., P.H. Jerie, P.D. Mitchell and, I. Goodwin. 2000b. Long-term effects of restricted root volume and regulated deficit irrigation on peach: II. Productivity and water use. J. Amer. Soc. Hort. Sci. 125:143-148.
Bonachela, S., F. Orgaz, F. Villalobos, and E. Fereres. 2001. Evaporation from the soil in the olive orchards under drip irrigation. Irr. Sci. 20:65-71.

Chalmers, D.J., P.D. Mitchell, and L. van Heek. 1981. Control of peach tree growth and productivity by regulated water supply, tree density and summer pruning. J. Amer. Soc. Hort. Sci. 106:307-312.

Doorenbos, J. and A.H. Kassam. 1979. Yield response to water. FAO Irrigation and drainage paper No. 33. Food and Agriculture Organization of the United Nations, Rome.

Doorenbos, J. and W.O. Pruitt. 1974. Crop water requirements. FAO Irrigation and drainage paper No. 24. Food Agr. Org.U.N., Rome.

Fereres, E. and F. Ceña. 1997. Social benefits and environmental constraints of irrigation in an era of water scarcity, p. 128-136. In: M. Kay, T. Franks, and L. Smith (eds.). Water: Economics, management and demand. E \& FNSPON, Chapman and Hall, London.

Fereres, E. and D. Goldhamer. 1990. Deciduous fruit and nut trees, p. 987-1017. In: B.A. Stewart and D.R. Nielsen (eds.). Irrigation of Agricultural Crops-Agronomy Monograph No. 30. Amer. Soc. Agron., Madison.

Ginestar,C. and J.R. Castel. 1996. Responses of young clementine citrus trees to water stress during different phenological periods. J. Hort. Sci. 71: 551-559.

Goldhamer D.A. 1999. Regulated deficit irrigation for California canning olives. Acta Hort. 474:369-372.

Goldhamer, D.A., J. Dunai, and L.F. Ferguson. 1994. Irrigation requirements of olive trees and responses to sustained deficit irrigation. Acta Hort. 356:172-175.

Goldhamer, D.A. and E. Fereres. 2001. Irrigation scheduling protocols using continuously recorded trunk diameter measurements. Irr. Sci. 20:155-125.

Inglese, P., E. Barone, and G. Gullo 1996. The effect of complementary irrigation on fruit growth, ripening pattern and oil characteristics of olive (Olea europaea $\mathrm{L}$.) cv. Carolea. J. Hort. Sci. 71:257-263

International Olive Oil Council (IOCC). 2001. Mediterranean flavours and the professional kitchen conference, Napa Valley, California. Olivae 87:20.

Lavee, S., M. Nashef, M. Wodner, and H. Harshemesh. 1990. The effect of complementary irrigation added to old olive trees (Olea europaea $\mathrm{L}$.) cv. Souri on fruit characteristics, yield and oil production. Adv. Hort. Sci. 4:135-138.

Lavee, S. and M. Wodner 1991. Factors affecting the nature of oil accumulation in fruit of olive (Olea europaea L.) cultivars. J. Hort. Sci. 66:583-591.

Mitchell, P.D., P.H. van den Ende, and D.J. Chalmers. 1989. Responses of 'Bartlett' pear to withholding irrigation, regulated deficit irrigation and tree spacing. J. Amer. Soc. Hort. Sci. 114:15-19.

Moriana, A. 2001. Relaciones hídricas en olivo (Olea europaea L.) bajo riego deficitario. $\mathrm{PhD}$ thesis. Univ. Cordoba, Spain.

Moriana, A., F. Villalobos, and E. Fereres. 2002. Stomatal and photosynthetic responses of olive (Olea europaea L.) leaves to water deficits. Plant Cell Environ. 25:395-405.

Naor, A. 2001. Irrigation and crop load influence fruit size and water relations in field-grown 'Spadona' Pear. J. Amer. Soc. Hort. Sci. 126:252-255.

Orgaz, F. and E. Fereres. 1997. Riego, p. 251-272. In: D. Barranco, R. FernándezEscobar and L. Rallo (eds.). El cultivo del olivo. Mundi Prensa, Madrid.

Orgaz, F., L. Mateos, and E. Fereres. 1992. Season length and cultivar determine the optimum evapotranspiration deficit in cotton. Agron. J. 84:700-706.

Pastor, M., J. Castro, M.J. Mariscal, V. Vega, F. Orgaz, E. Fereres, and J. Hidalgo. 1999. Respuesta del olivar tradicional a diferentes estrategias y dosis de agua de riego. Invest. Agr. 14:393-404.

Patumi, M., R. D’Andria, G. Fontanazza, G. Morelli, P. Giorio, and G. Sorrentino. 1999. Yield and oil quality of intensively trained trees of three cultivars of olive (Olea europaea L.) under different irrigation regimes. J. Hort. Sci. Biotechnol. 74:729-737.

Rallo, L and M.P. Suarez. 1989. Seasonal distribution of dry matter within the olive bearing limb. Adv. Hort. Sci. 3:55-59.

Stevenson, M.T. and K.A. Shackel. 1998. Alternate bearing in pistachio as a masting phenomenon: construction cost of reproduction versus vegetative growth and storage. J. Amer. Soc. Hort. Sci. 123:1069-1075

Stewart, J.I. and R.H. Hagan. 1973. Functions to predict effects of crop water deficits. J. Irr. Drain. Div. ASCE 99:421-439.

Vaux, H.J. and W.O. Pruitt. 1983. Crop-water production functions, p. 61-97. In: D. Hillel (eds.). Advances in irrigation. vol 2. Academic Press, New York.

Villalobos, F.J., F. Orgaz, L. Testi, and E. Fereres. 2000. Measurement and modeling of evaporation of olive (Olea europaea L.) orchards. Eur. J. Agron. 13:155-163. 